\title{
Synthesis, Characterisation and Biological Activity of a New Mannich Base and It's Metal Complexes
}

\author{
M. SIVAKAMI, B. NATARAJAN* and M. VIJAYACHANDRASEKAR
}

Department of Chemistry, Faculty of Engineering and Technology, SRM University, Kattankulathur, Tamilnadu, India

sivakamisudhasankar@gmail.com

Received 11 February 2014 / Accepted 15 March 2014

\begin{abstract}
Mannich bases play a major role in biological processes. In view of this a new Mannich base 1-(2,5-dioxo pyrolidin-1-yl)(4-methoxy phenyl)(methyl)thiourea (SMBTU) was synthesized using succinimide, methoxybenzaldehyde and thiourea. The complexation behaviour of this ligand with $\mathrm{Mn}(\mathrm{II}), \mathrm{Ni}(\mathrm{II}), \mathrm{Cu}(\mathrm{II})$ and $\mathrm{Zn}$ (II) ions were studied. The structural features of the complexes were analyzed by elemental analysis, IR, UV-Visible, ${ }^{1} \mathrm{H},{ }^{13} \mathrm{C}$ NMR spectra and magnetic susceptibility measurements. The anti microbial activity of the ligand and its complexes has been extensively studied against some of the gram-positive and gram-negative bacterium. The ligand and all the metal complexes showed antimicrobial activity.
\end{abstract}

Keywords: Mannich base, SMBTU, Metal complexes, Antimicrobial activity

\section{Introduction}

The versatile chemistry of Mannich base offer major opportunities for creating new molecular structures for variety of commercial applications. About $40 \%$ of articles related to Mannich bases are published in pharmaceutical journals. Mannich bases are very popular for their applications in polymer chemistry, surfactants ${ }^{1}$ detergent additives ${ }^{2}$ and antioxidants ${ }^{3}$. Mannich reaction is one of the most important multi-component reactions in organic synthesis. It provides $\beta$-amino carbonyl compounds and natural products. They possess a wide range of biological applications such as diuretic ${ }^{4}$, antipsychotic ${ }^{5}$, oxytocic ${ }^{6}$, anticonvulsant $^{7}$, muscle relaxant $^{8}$, antimalarial ${ }^{9,10}$, antiviral ${ }^{11}$ and anticancer ${ }^{12}$ agents. Mannich bases when they form complexes with metal ions exhibit enhanced biological activities. Such increased activity of metal chelates can be explained on the basis of overtone concept and chelation theory. According to the overtone concept of cell permeability, the lipid membrane that surrounds the cell favours the passage of only lipid-soluble materials in which liposolubility is an important factor that controls the anti microbial activity. On chelation it increases the delocalization of $\pi$-electrons over the whole chelate ring and enhances the lipophilicity of complexes. This lipophilicity enhances the penetration of complexes into the lipid membranes and blocks the metal binding sites in enzymes of micro 
organisms. These complexes also disturb the respiration process of the cell and thus block the synthesis of proteins, which restricts further growth of the organism. Hence it is paramount to develop the simple synthetic route for Mannich bases from widely available compounds using simple solvents.

\section{Experimental}

All the reagents used were of A.R grade and the solvents used were commercial products of the highest available purity. Elemental analysis was performed using Perkin Elmer 2400 analyzer were found within $\pm 0.5 \%$. The IR spectra were recorded as $\mathrm{KBr}$ pellets on Perkin Elmer 1000 unit instrument. Absorbance in UV-Visible region was recorded in DMF solution using UV-Visible spectrometer. The ${ }^{1} \mathrm{H} \&{ }^{13} \mathrm{C}$ NMR of the ligand was recorded in a Bruker instrument employing TMS as internal reference and DMSO as $-\mathrm{d}_{6}$ as solvent. The Mass spectral study of the ligand was carried out using LC Mass spectrometer. Magnetic susceptibility measurements at room temperature were made by using Guoy magnetic balance for the metal complexes. Electrical conductivity of metal complexes were measured at room temperature in $\sim 10^{-3} \mathrm{M}$ ethanol solution using a Systronics direct reading digital conductivity meter -304 with dip type conductivity cell.

\section{General procedure for the preparation of SMBTU}

In the preparation of SMBTU ligand, succinimide ( $1 \mathrm{~g}, 0.1 \mathrm{~mol})$, methoxybenzaldehyde $(1.37 \mathrm{~g}, 0.1 \mathrm{~mol})$ and thiourea $(0.73 \mathrm{~g}, 0.1 \mathrm{~mol})$ were taken in $1: 1: 1$ molar ratio in aqueous solution and the mixture was stirred in a magnetic stirrer at room temperature for 8-10 hours. After a week a solid product formed was filtered, washed with water to remove the unreacted succinimide, methoxybenzaldehyde and thiourea followed by $n$ hexane. The product was then dried and recrystallized in methanol. Yield was $80 \%$ (Scheme 1).

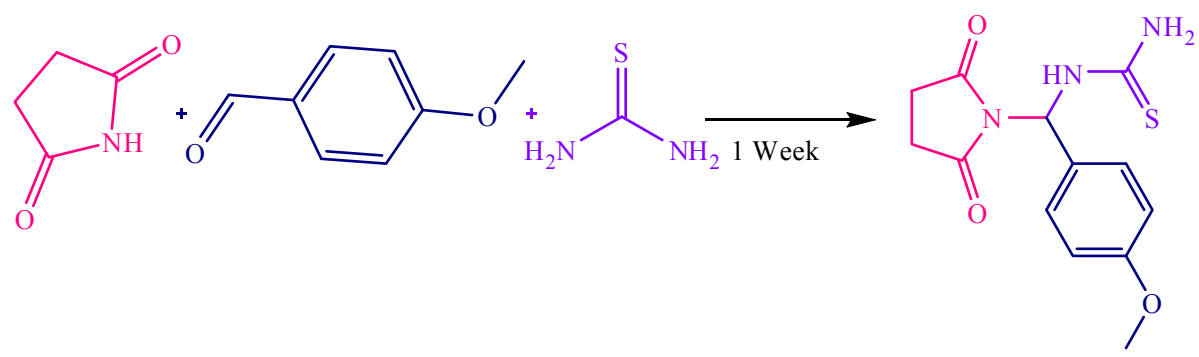

Scheme 1. Preparation of SMBTU

Synthesis of metal complexes with SMBTU

$\mathrm{Mn}(\mathrm{II}), \mathrm{Ni}(\mathrm{II}), \mathrm{Cu}(\mathrm{II})$ and $\mathrm{Zn}(\mathrm{II})$ complexes have been synthesized using SMBTU as ligand. All the metal complexes were synthesized by mixing aqueous solution of the metal salts with methanolic solution of the ligand. The reaction mixture was gently stirred and kept aside. After few days the solid complex formed was filtered, washed with distilled water and dried in vacuum (Scheme 2).

\section{Results and Discussion}

All the complexes are stable at room temperature. They are in insoluble in water and sparingly soluble in common organic solvents but soluble in DMSO. The elemental analyses of the products are listed in Table 1 . 
Table 1. Eelemental analysis data of the ligand SMBTU and its metal complexes

\begin{tabular}{|c|c|c|c|c|c|c|c|}
\hline \multirow{2}{*}{ Compound } & \multirow{2}{*}{$\begin{array}{l}\text { Yield } \\
\%\end{array}$} & \multicolumn{6}{|c|}{ Found (Calculated \%) } \\
\hline & & $\mathrm{C}$ & $\mathrm{H}$ & $\mathrm{N}$ & $\mathrm{O}$ & $\mathrm{S}$ & $\mathrm{M}$ \\
\hline $\begin{array}{l}\text { SMBTU } \\
\left(\mathrm{C}_{13} \mathrm{H}_{15} \mathrm{~N}_{3} \mathrm{O}_{3} \mathrm{~S}\right)\end{array}$ & 85 & $\begin{array}{c}53.23 \\
(53.12)\end{array}$ & $\begin{array}{c}5.15 \\
(4.98)\end{array}$ & $\begin{array}{c}14.32 \\
(14.07)\end{array}$ & $\begin{array}{c}16.36 \\
(16.25)\end{array}$ & $\begin{array}{c}10.93 \\
(10.78)\end{array}$ & - \\
\hline $\begin{array}{l}\mathrm{NiSO}_{4} \cdot 2 \mathrm{H}_{2} \mathrm{OSMBTU} \\
\left(\mathrm{C}_{14} \mathrm{H}_{16} \mathrm{~N}_{3} \mathrm{NiO}_{7} \mathrm{~S}_{2}\right)\end{array}$ & 78 & $\begin{array}{l}36.47 \\
(36.15)\end{array}$ & $\begin{array}{c}3.50 \\
(3.12)\end{array}$ & $\begin{array}{c}9.11 \\
(8.97)\end{array}$ & $\begin{array}{c}24.29 \\
(23.98)\end{array}$ & $\begin{array}{c}13.91 \\
(13.83)\end{array}$ & $\begin{array}{l}12.73 \\
(12.54)\end{array}$ \\
\hline $\begin{array}{l}\mathrm{MnSO}_{4} \cdot 2 \mathrm{H}_{2} \mathrm{OSMBTU} \\
\left(\mathrm{C}_{14} \mathrm{H}_{16} \mathrm{MnN}_{3} \mathrm{O}_{7} \mathrm{~S}_{2}\right)\end{array}$ & 82 & $\begin{array}{c}36.77 \\
(36.65)\end{array}$ & $\begin{array}{c}3.53 \\
(3.12)\end{array}$ & $\begin{array}{c}9.19 \\
(8.99)\end{array}$ & $\begin{array}{c}24.49 \\
(24.32)\end{array}$ & $\begin{array}{c}14.02 \\
(14.01)\end{array}$ & $\begin{array}{c}12.01 \\
(11.89)\end{array}$ \\
\hline $\begin{array}{l}\mathrm{ZnSO}_{4} \cdot \mathrm{SMBTU} \\
\left(\mathrm{C}_{14} \mathrm{H}_{16} \mathrm{~N}_{3} \mathrm{O}_{7} \mathrm{~S}_{2} \mathrm{Zn}\right)\end{array}$ & 80 & $\begin{array}{l}35.94 \\
(35.87)\end{array}$ & $\begin{array}{c}3.45 \\
(3.32)\end{array}$ & $\begin{array}{c}8.98 \\
(8.87)\end{array}$ & $\begin{array}{l}23.94 \\
(23.75)\end{array}$ & $\begin{array}{c}13.71 \\
(13.67)\end{array}$ & $\begin{array}{c}13.98 \\
(13.77)\end{array}$ \\
\hline $\begin{array}{l}\mathrm{CuSO}_{4} \cdot \mathrm{SMBTU} \\
\left(\mathrm{C}_{14} \mathrm{H}_{16} \mathrm{CuN}_{3} \mathrm{O}_{7} \mathrm{~S}_{2}\right)\end{array}$ & 85 & $\begin{array}{c}36.09 \\
(35.98)\end{array}$ & $\begin{array}{c}3.46 \\
(3.15)\end{array}$ & $\begin{array}{c}9.02 \\
(8.97)\end{array}$ & $\begin{array}{c}24.04 \\
(23.89)\end{array}$ & $\begin{array}{l}13.76 \\
(13.65)\end{array}$ & $\begin{array}{c}13.64 \\
(13.38)\end{array}$ \\
\hline
\end{tabular}
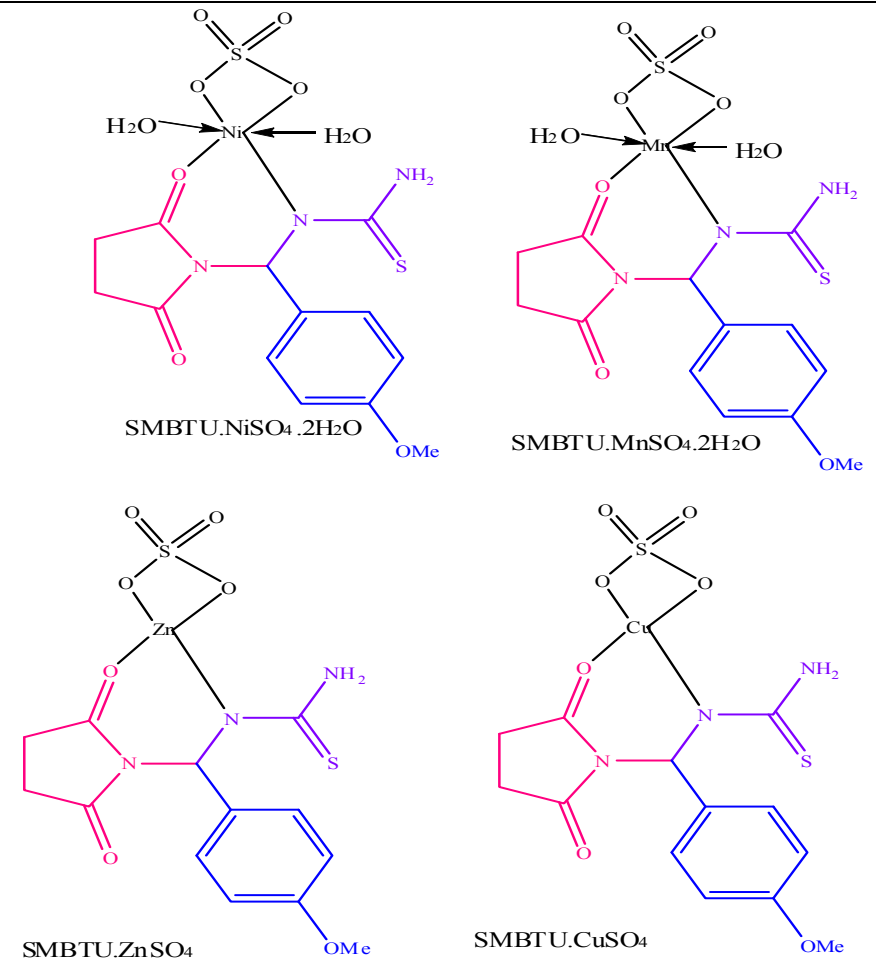

Scheme 2. Proposed structures for the metal complexes

\section{Electronic spectrum}

The colours, magnetic moment and electronic spectral data of $\mathrm{Mn}(\mathrm{II}), \mathrm{Cu}(\mathrm{II})$ and $\mathrm{Ni}(\mathrm{II})$ complexes are summarised in Table 2. The electronic spectra of $\mathrm{Mn}$ (II) complex display absorption bands in the regions $18021 \mathrm{~cm}^{-1}, 24967 \mathrm{~cm}^{-1}$ and $28305 \mathrm{~cm}^{-1}$ which may be assigned to ${ }^{6} \mathrm{~A}_{1 \mathrm{~g}} \rightarrow{ }^{4} \mathrm{~T}_{1 \mathrm{~g}}, \mathrm{~A}_{1 \mathrm{~g}} \rightarrow{ }^{4} \mathrm{E}_{\mathrm{g}}+{ }^{4} \mathrm{~A}_{1 \mathrm{~g}}$ and ${ }^{6} \mathrm{~A} 1 \mathrm{~g} \rightarrow{ }^{4} \mathrm{~T}_{2 \mathrm{~g}}$ respectively. These spectral features ${ }^{13-15}$ indicate octahedral stereochemistry of $\mathrm{Mn}(\mathrm{II})$ and it is further supported by the observed magnetic moment values ${ }^{16-18}$ at 5.31B.M. 
Table 2. Magnetic moment, assigned transitions with $\lambda_{\max }$ and geometry of the metal complexes

\begin{tabular}{|c|c|c|c|c|}
\hline Complex & $\begin{array}{c}\text { Colour, } \\
\mu_{\text {eff. }} \text { B.M }\end{array}$ & Geometry & $\lambda_{\max }, \mathrm{cm}^{-1}$ & $\begin{array}{c}\text { Transition } \\
\text { Assignment }\end{array}$ \\
\hline $\mathrm{MnSO}_{4} \cdot 2 \mathrm{H}_{2} \mathrm{O} \cdot \mathrm{SMBTU}$ & $\begin{array}{c}\text { Colourless } \\
\quad(5.31)\end{array}$ & Octahedral & $\begin{array}{l}18021 \\
24967 \\
28305\end{array}$ & ${ }^{6} \mathrm{~A} \quad{ }^{4} \mathrm{~T}$ \\
\hline $\mathrm{CuSO}_{4} \cdot \mathrm{SMBTU}$ & $\begin{array}{c}\text { Leaf green } \\
\quad(2.83)\end{array}$ & $\begin{array}{l}\text { Distorted } \\
\text { tetrahedral }\end{array}$ & $\begin{array}{l}9425 \\
12968 \\
15317 \\
35100\end{array}$ & 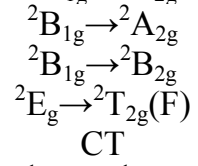 \\
\hline $\mathrm{NiSO}_{4} \cdot 2 \mathrm{H}_{2} \mathrm{O} . \mathrm{SMBTU}$ & $\begin{array}{l}\text { Green } \\
(3.97)\end{array}$ & Octahedral & 19380 & ${ }^{1} \mathrm{~A}_{1 \mathrm{~g}} \rightarrow{ }^{1} \mathrm{~A}_{2 \mathrm{~g}}$ \\
\hline
\end{tabular}

The sulphate complex of $\mathrm{Cu}(\mathrm{II})$ exhibit bands at $9425 \mathrm{~cm}^{-1}, 12968 \mathrm{~cm}^{-1}, 15317 \mathrm{~cm}^{-1}$ and $35100 \mathrm{~cm}^{-1}$ and the magnetic moment was observed at 2.83 B.M. These observations suggest distorted tetrahedral geometry for this complex.

The Ni(II) complex exhibits absorption band at $19380 \mathrm{~cm}^{-1}$ which is assigned as ${ }^{1} \mathrm{~A}_{\mathrm{gg}} \rightarrow{ }^{1}$ $\mathrm{A}_{2 \mathrm{~g}}$ transition confirming octahedral geometry ${ }^{19}$ for this complex. The absence of any band below $10000 \mathrm{~cm}^{-1}$ eliminates the possibility of tetrahedral environment in the nickel complex.

The $\mathrm{Zn}$ complexes do not display electronic transitions and they are diamagnetic in nature. However on the basis of 1:1 stoichiometry, molar conductance and IR spectral data, these metal complexes are tentatively assigned for the usual four-coordinated tetrahedral geometry.

Table 3. Characteristic IR Absorption frequencies $\left(\mathrm{cm}^{-1}\right)$ of SMBTU and its metal complexes

\begin{tabular}{lccccccccccc}
\hline \multicolumn{1}{c}{ Compound } & $v_{\mathrm{C}=\mathrm{O}}$ & $\mathrm{N}_{\mathrm{NH}}$ & $v_{\mathrm{NH} 2}$ & $\mathrm{~N}_{N C N}$ & $v_{2}$ & $v_{3}$ & $v_{O H}$ & $\delta_{\mathrm{HOH}}$ & $P w_{\mathrm{HOH}}$ & $v_{M-O}$ & $M-N$ \\
\hline SMBTU & 1689 & 3315 & 3408 & 1471 & - & - & - & - & - & - & - \\
$\mathrm{MnSO}_{4}$ SMBTU & 1690 & 3319 & 3405 & 1380 & 822 & 1076 & 3778 & 1627 & 637 & 427 & 587 \\
$\mathrm{NiSO}_{4}$. SMBTU & 1701 & 3320 & 3380 & 1381 & 817 & 925 & 3774 & 1624 & 635 & 427 & 493 \\
$\mathrm{CuSO}_{4}$. SMBTU & 1772 & 3280 & 3400 & 1366 & 817 & 917 & - & - & - & 411 & 550 \\
$\mathrm{ZnSO}_{4}$. SMBTU & 1705 & 3312 & 3395 & 1401 & 816 & 923 & 3775 & 1626 & 623 & 418 & 479 \\
\hline
\end{tabular}

Spectral studies for $S M B T U$

${ }^{1}$ H NMR: (DMSO/TMS, 500.3MHz): $\delta 2.56(\mathrm{~s}, 4 \mathrm{H}), 3.77$ (s, 3H), 6.41 (bs, 2H), $6.93(\mathrm{~d}$, $2 \mathrm{H}, J=9.00 \mathrm{~Hz}), 6.93(\mathrm{~d}, 2 \mathrm{H}, J=8.50 \mathrm{~Hz}), 7.79(\mathrm{~s}, 1 \mathrm{H}), 10.10(\mathrm{~s}, 1 \mathrm{H}), 11.06(\mathrm{~s}, 1 \mathrm{H}), \mathrm{ppm}$; ${ }^{13}$ C NMR: (DMSO/TMS, $\left.125.7 \mathrm{MHz}\right): \delta 179.4,156.7,137.9,133.8,131.1,128.7,128.2$, 40.0, 29.5 ppm; LC Mass: Calcd. For $\mathrm{C}_{13} \mathrm{H}_{16} \mathrm{~N}_{4} \mathrm{O}_{4} \mathrm{~m} / z=293.2905$; Found 292.32.

\section{Antibacterial activity}

The metal complexes showed effective antibacterial activity against Escherichia coli (Gram negative), Bacillus sp.(Gram positive) and Staphylococcus aureus (Gram positive). 24 hours grown culture was used as an inoculum on nutrient agar media. Disc diffusion method was performed to ascertain antibacterial activity of the metal complexes in triplicates. The metal complexes of the ligand showed inhibition action against both gram positive as well as gram negative bacteria involved in the study. The $\mathrm{NiSO}_{4}$ metal complex showed maximum zone of inhibition of $13 \mathrm{~mm}$ against S.aureus. The reason for this is the breakdown of cell wall components of the bacteria. The zone of inhibition of various metal complexes at a concentration of $50 \mu \mathrm{g} / \mu \mathrm{L}$ each is given in Table 4 . This study evidences the antibacterial activity of the metal complexes. The ligand has shown minimum antibacterial activity only. 
Table 4. Zone of inhibition (mm) for metal complexes of SMBTU against Escherchia coli (Gram negative) and Staphylococcus aureus (Gram positive)

\begin{tabular}{cccc}
\hline \multirow{2}{*}{ S.No. } & \multirow{2}{*}{ Compound } & \multicolumn{2}{c}{ Zone of Inhibition $(\mathrm{mm})$} \\
\cline { 3 - 4 } & & E.coli & Staphylococcus aureus \\
\hline 1. & $\mathrm{CuSO}_{4}$ SBTU & 9 & 7 \\
2. & $\mathrm{ZnSO}_{4}$ SBTU & 8 & 11 \\
3. & $\mathrm{NiSO}_{4}$ SBTU & 10 & 13 \\
4. & Streptomycin & 15 & 25 \\
\hline
\end{tabular}

\section{Conclusion}

We have synthesised a new Mannich base and some of its metal complexes. The metal complexes were characterized by various chemical and spectral analysis. Based on the spectal data, the ligand was found to coordinate through carbonyl oxygen of succinimide and amino nitrogen of thiourea. The synthesised metal complexes showed antimicrobial activities.

\section{References}

1. $\quad$ Karll R E and Lee R J, US Patent, US 4384 138, 1983.

2. Otto F P, US Patent, US 3649 229, 1972.

3. Horodysky A G and Kaminski J M, US Patent, US 4394 278, 1983.

4. Lee L M, Plattner J J, Ours C W, Horrom B W, Smital J R, Martin Y C, Pernet A G, Bunnell P R, El Masry S E and Dodge P W, J Med Chem., 1984, 27(12), 1579-1587; DOI:10.1021/jm00378a010

5. Scott M K, Martin G E, DiStefano D L, Fedde C L, Kukla M J, Barrett D L, Baldy W J, Jr Elgin R J, Kesslick J M, Mathiasen J R, Strank R P and Vaught J L, J Med Chem., 1992, 35, 552-558; DOI:10.1021/jm00081a018

6. Cohen A, Hall R A, Heath-Brown B, Parker M W and Rees A H, British J Pharmacol Chemother., 1957, 12(2), 194-208.

7. Borenstein M R and Doukas P H, J Pharm Sci., 1987, 76(4), 300-302; DOI:10.1002/jps.2600760407

8. Shiozawa A, Narita K, Izumi G, Kurashige S, Sakitama K and Ishikawa M, Eur J Med Chem., 1995, 30(1), 85-94; DOI:10.1016/0223-5234(96)88213-4

9. Barlin G B and Jiravinya C, Aus J Chem., 1990, 43, 1175.

10. Barlin G B, Jiravinya C and Yan J H, Aus J Chem., 1991, 44, 677.

11. Edwards M L, Ritter H W, Stemerick D M and Stewart K T, J Med Chem., 1983, 26(3), 431-436; DOI:10.1021/jm00357a020

12. Dimmock J R and Kumar P, Curr Med Chem., 1997, 4, 1-22.

13. Goodgame D M L, Goodgame M and Cotton F A, J Am Chem Soc., 1961, 83(20), 4161-4167; DOI:10.1021/ja01481a014

14 Lever A B P, Inorganic Electronic Spectroscopy, Elsevier, Amsterdam, 1968.

15. Drago R S, Physical Methods in Inorganic Chemistry, Affiliated East West Press, New Delhi, 1978.

16. Jorgensen C K, Advan Chem Phys., 1963, 5, 33.

17. Aliakbar Dehno Khalaji, Der Chem Sinica, 2011, 2(6), 7.

18. Seema I Habib, Mohammed A Baseer and Prafullakumar A Kulkarni, Der Chem Sinica, 2011, 2(1), 27-32.

19. Kasim A N M, Venkappayya D and Prabhu G V, J Indian Chem Soc., 7667, 1999. 